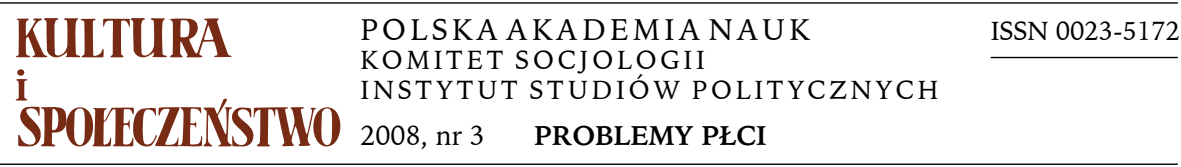

EWA MALINOWSKA

Uniwersytet Łódzki

\title{
PŁEĆ KULTUROWA A PRZESTRZEŃ SPOŁECZNA
}

Opracowanie to ma charakter teoretyczny; jest kontynuacją próby zastosowania koncepcji ekologii ludzkiej Floriana Znanieckiego do analizy funkcjonowania i przemian społeczeństwa patriarchalnego (Malinowska 2008). Podjęto tu problematykę przestrzennych aspektów funkcjonowania patriarchatu, których identyfikacja, a zwłaszcza socjologiczny opis i wyjaśnienie stają się pełniejsze dzięki wykorzystaniu wspomnianej koncepcji. Te zagadnienia to: (1) wpływ płci na doświadczanie przestrzeni oraz (2) zbiorowości płci a przestrzeń; społeczno-przestrzenne przejawy wyrównywania społecznego statusu kobiet i mężczyzn.

Przedmiotem wcześniejszych rozważań była teza, że patriarchalny charakter kulturowego modelu społeczeństwa powoduje, iż przyznawanie jednostce pozycji ekologicznych w różnych typach przestrzeni jest przede wszystkim uwarunkowane płcią rodzajową, jest następstwem funkcjonowania kulturowych koncepcji „kobiecości” i „męskości”, określających nie tylko pożądane cechy osobowości i wyglądu człowieka, ale także role zawodowe i inne role społeczne „odpowiednie" dla kobiet i te, które pełnić może tylko mężczyzna. Przedstawiono tam przede wszystkim argumenty przemawiające za uwzględnieniem patriarchalnego charakteru kultury $\mathrm{w}$ - prowadzonej ze „współczynnikiem humanistycznym" - analizie procesu nadawania jednostce pozycji ekologicznych. Zreferowano także problem relacji między pozycją ekologiczną jednostki w różnych typach przestrzeni a jej płcią, głównie w odniesieniu do kobiet (Malinowska 2008).

Te rozważania dotyczą modelu społeczeństwa patriarchalnego i jego przemian. Zdając sobie $\mathrm{w}$ pełni sprawę $\mathrm{z}$ istnienia wielu odmian rzeczywistego patriarchatu, na użytek tej pracy przyjęto, że w codziennym doświadczeniu jednostek ludzkich patriarchalny model stosunków społecznych obiektywizuje się jednak w zaskakująco podobny sposób w różnych kulturach i epokach. Jed-

Adres do korespondencji: ewamal@uni.lodz.pl 
nocześnie - starano się uwzględniać występowanie tendencji (i empirycznych przejawów) zmian patriarchalnego modelu społeczeństwa w model społeczeństwa egalitarnego, czyli zorganizowanego na zasadzie równego statusu kobiet i mężczyzn. Biorąc pod uwagę charakter i cel publikacji nie uwzględniono wewnętrznego zróżnicowania zbiorowości płci pod względem takich cech jak rasa, klasa społeczna, etniczność, wiek, wyznanie, to jest mających także zasadnicze znaczenie stratyfikujące (Bradley 2008, s. 225-228). Uznano to bowiem, przynajmniej na tym etapie pracy, za niewykonalne. Podobnie uczynił zresztą swego czasu Florian Znaniecki, celowo pomijając w analizach „skład i strukturę grupy” i proponując odłożenie tego zadania „na przyszłość” (Znaniecki 1938, s. 93).

Za Florianem Znanieckim przyjęto także typologię „zespołów ludzkich”, wyróżniając: rodzinę, zespoły lokalne i ponadlokalne (państwo) wraz z przestrzeniami pozostającymi „w ich władaniu”.

\section{PŁEĆ KULTUROWA A DOŚWIADCZANIE PRZESTRZENI}

W swej koncepcji ekologii ludzkiej, nawiązującej do podstawowych założeń socjologii humanistycznej, Florian Znaniecki postulował, żeby „badacz kultury" odróżniał przestrzeń fizyczną od społecznej i ujmował ją inaczej niż czynią to przedstawiciele nauk ścisłych i przyrodniczych. Proponował, aby socjolog traktował przestrzeń „[...] ze współczynnikiem humanistycznym, tj. tak, jak jest doświadczana przez podmioty ludzkie, których kulturę bada" (Znaniecki 1938, s. 90). Postulując uwzględnianie w badaniach socjologicznych kulturowego kontekstu doświadczeń podmiotu Znaniecki pominął najdawniejszy, najszerszy i najogólniejszy jego aspekt, a mianowicie patriarchalny charakter społeczeństwa zachodniego i jego kultury (Malinowska 2008).

Niezależnie od konkretnej historycznej formy społeczeństwa patriarchalnego zawsze jednocześnie funkcjonują w nim system płci biologicznej i nadbudowana nad nią społeczna koncepcja kobiety i mężczyzny oraz system ekonomicznej dyskryminacji kobiet (Humm 1993). „Kobiecość” i „męskość” określają idealne cechy wyglądu, osobowości oraz odpowiednie dla danej kategorii płci pakiety ról społecznych, w tym - ról zawodowych. Jeśli chodzi o ten ostatni z elementów kulturowego konstruktu płci, to kobietom powierza się przede wszystkim pełnienie ról uwarunkowanych biologicznymi cechami żeńskiego organizmu. Są to role „bliskie naturze”, reprodukcyjne. Ich wykonywanie nie wiąże się z udziałem w sprawowaniu władzy, nie jest opłacane. Role te nie wymagają legitymowania się określonym poziomem wykształcenia, zdobywania formalnie potwierdzonych kwalifikacji ani czuwania nad intelektualnym rozwojem. Jako takie - nie zapewniają ich odtwórczyniom prestiżu społecznego porównywalnego z tym, jakim cieszą się mężczyźni, będący przede wszystkim wykonawcami ról „bliskich kulturze”, przynoszących stały dochód i udział w sprawowaniu władzy (Ortner 1982). Innymi słowy, patriarchat to 
„system władzy i dominacji mężczyzn nad kobietami, będący — za pośrednictwem swoich instytucji społecznych, ekonomicznych i politycznych —źródłem opresji kobiet" (Humm 1993, s. 158).

Uwzględnienie patriarchalnego kontekstu uczestnictwa społecznego człowieka pozwala zauważyć, że: po pierwsze - każda jednostka ludzka gromadzi swe doświadczenia społeczne funkcjonując jako kobieta albo jako mężczyzna, a po drugie — tylko jednostka ludzka płci męskiej może doświadczać przestrzeń jako podmiot społeczny, gdyż ma status i prawa podmiotu.

Zgodnie z teorią ekologii ludzkiej, przestrzeń zawłaszczają nawet luźne zespoły, zwłaszcza zespoły zorganizowane. W społeczeństwie patriarchalnym (choć podział pracy według płci i wieku dokonuje się w każdej kulturze) kategorie płci są głównymi zespołami, między którymi dokonuje się społeczny podział ról, a zatem także podział przestrzeni. Co ważniejsze - panujący tu model relacji między kategoriami płci sprawia, że mężczyźni, będący jedynym zbiorowym podmiotem, teoretycznie są także jedynym zespołem władającym przestrzenią. Zbiorowość kobiet natomiast może $\mathrm{z}$ ich upoważnienia używać przestrzeni, mówiąc językiem Floriana Znanieckiego - „dla wykonywania pewnych czynności zbiorowych”. Jednostki płci żeńskiej mogą posługiwać się daną przestrzenią także „przy wykonywaniu pewnych czynności indywidualnych”. Mogą też ją zawłaszczać, to znaczy utożsamiać się z nią, ale nie mogą nią dysponować, gdyż funkcjonują w niej na innych prawach niż mężczyźni. Ryzykowne jest zatem, powszechnie występujące, postrzeganie przestrzeni prywatnej jako „królestwa kobiet", obszaru kobiecego panowania, gdyż de facto władają nim mężczyźni. Co więcej - $\mathrm{w}$ tym typie społeczeństwa przestrzeń rodziny jest bezalternatywnie wskazana kobietom jako funkcjonalnie odpowiednia do wykonywania ról bliskich „naturze” i teoretycznie jest jedyną przestrzenią dostępną społecznemu doświadczeniu kobiet. Kobietom, podobnie jak dzieciom, nie powierza się bowiem ról społecznych, których pełnienie wymagałoby obecności w innych typach przestrzeni: „Kobiety, dzieci, słudzy daleko mniej mają do czynienia poza siedzibą rodzinną [...]" (Znaniecki 1938, s. 104).

Przyznanie człowiekowi występującemu w danej roli społecznej prawa obecności w pewnej przestrzeni Florian Znaniecki (1938, s. 94) określił mianem „pozycji ekologicznej”. Zgodnie z przyjętą koncepcją teoretyczną, najwcześniejsze pozycje ekologiczne zostają przyznane jednostkom przez kręgi rodzinne władające siedzibą rodziny, która ma charakter zamknięty (Znaniecki 1938, s. 96). Jak wspomniano, w modelowym społeczeństwie patriarchalnym siedziba tej grupy pozostaje we władaniu mężczyzn współtworzących dany krąg rodzinny, a dokładniej mężczyzny pełniącego rolę głowy rodziny. Zatem to raczej mężczyźni z kręgu rodzinnego (niż ten ostatni jako grupa władająca przestrzenią rodziny) nadają pierwotne pozycje ekologiczne. W cechach owej mikroprzestrzeni - takich jak jej rozległość, wielkość, wystrój, wyposażenie, złożoność struktury - manifestuje się głównie społeczna pozycja mężczyzny. Zakres i sposób dysponowania przez kobietę przestrzenią rodziny zależy od 
woli mężczyzny i pozostaje w bezpośrednim związku z jego statusem społecznym. W obrębie rodzinnej siedziby do dyspozycji kobiet pozostają jej fragmenty niezbędne do wykonywania funkcji wynikających z roli gospodyni, żony, matki i innych ról rodzinnych.

W społeczeństwie patriarchalnym zatem nawet w przestrzeni pozornie zdominowanej przez kobiety pozycje ekologiczne kobiet i mężczyzn są nierówne na niekorzyść kobiet. Nierówne członkostwo społeczne - także w takiej grupie, jaką jest patriarchalna rodzina, oparte na „poddaństwie” i uprzedmiotowieniu kobiet oraz na podmiotowości i dominacji mężczyzn - skutkuje nierównymi prawami do obecności w rodzinnej siedzibie.

Zdaniem autora koncepcji ekologii ludzkiej, jednostki, z wyjątkiem osób pełniących określone role zawodowe (i w sytuacjach, kiedy je pełnią), „nigdy nie doświadczają jakiejś powszechnej, obiektywnej, bezjakościowej, niezmiennej, nieograniczenie podzielnej przestrzeni [...]". Przeciwnie - podmiotowi dane „[...] są w doświadczeniu niezliczone "przestrzenie» jakościowo różnorodne, ograniczone, niepodzielne, zmienne, a przy tym dodatnio lub ujemnie oceniane" (Znaniecki 1938, s. 91).

W modelowym społeczeństwie patriarchalnym doświadczeniu kobiet dostępne są przestrzenie o specyficznych cechach fizycznych i społecznych. Wykorzystując do ich charakterystyki typologię komponentów przestrzeni miejskiej zaproponowaną przez Aleksandra Wallisa można powiedzieć, że są one raczej niewielkie i nierozległe, zamknięte, o typowym przeznaczeniu powiązanym $z$ funkcjami pełnionymi przez rodzinę. W praktyce jedynym elementem różnicującym przestrzenie dostępne doświadczeniu kobiet jest ich zindywidualizowana oprawa.

Mikroprzestrzenie mają specyfikę społeczną. Przede wszystkim są areną określonego typu stosunków społecznych: personalnych i bezpośrednich. Wypełniają je stale te same osoby, połączone silną więzią społeczną, wzmocnioną relacją pokrewieństwa (co nie znaczy, że jednakową w przypadku wszystkich członków zespołu rodzinnego). Społeczna kontrola zachowań w tej przestrzeni, zwłaszcza osób podporządkowanych — kobiet, dzieci i służby (por. Znaniecki 1938) - jest bezpośrednia, całkowita, wzajemna i oczywiście realizowana z myślą o utrzymaniu panującego ładu normatywnego i zbudowanego na nim porządku patriarchalnego (a więc służy reprodukcji władzy mężczyzn i podporządkowania kobiet).

Kobiety zatem doświadczają stale przestrzeni tego samego typu. W takich warunkach społeczno-przestrzennych rozwijają one i ćwiczą zdolności do nawiązywania głębokich relacji społecznych, przywiązywania znaczenia do jakości procesu komunikacji między ludźmi, kierowania się emocjami i empatią, trenują cierpliwość w postępowaniu z osobami bliskimi, krytycyzm wobec siebie lub... narcyzm itp. To wszystko, co mieści się w kulturowej koncepcji „kobiecej” osobowości i co, z mocy tej samej definicji, jest zlokalizowane w mikroprzestrzeniach, w przyszłości musi utrudnić kobietom ruchliwość społeczno-prze- 
strzenną w kierunku zespołów lokalnych i ponadlokalnych, lansowanie tam swoich wartości oraz zaakceptowanie przez kobiety wartości przestrzennych i nieprzestrzennych tych grup.

Co więcej, jeśli różnorodność społecznych przestrzeni dostępnych doświadczeniu ludzkiemu potraktować jako wartość autoteliczną, znacząco wzbogacającą życie człowieka, to $\mathrm{w}$ społeczeństwie patriarchalnym kobiety są pozbawione możliwości jej realizacji. Podobnie jeśli chodzi o konkretyzację i nieamorficzność doświadczanych przestrzeni. Podmiot społeczny (czytaj: mężczyzna) konkretyzuje i ogranicza przestrzenie w rezultacie dotychczasowej bogatej praktyki w zakresie ich poznawania i w efekcie dokonywanych wyborów. Sprzyja to oczywiście nabieraniu wprawy w dokonywaniu trafnych ocen przestrzeni z wszystkimi tego konsekwencjami (na przykład pozytywna ocena danej przestrzeni jest ważnym czynnikiem ułatwiającym proces utożsamiania się z nią, nabierania poczucia zakorzenienia). W przypadku kobiet konkretność i niepodzielność doświadczanych przestrzeni jest jednak rezultatem ograniczonego dostępu do innych rodzajów mikroprzestrzeni i wysokiej niedostępności pozostałych typów przestrzeni, to znaczy należących do zespołów ludzkich funkcjonujących na zewnątrz rodziny i jej siedziby. Monotonia kobiecych doświadczeń przestrzennych stwarza, zamiast psychospołecznego komfortu, jaki mają mężczyźni dzięki pluralizmowi swych społecznoprzestrzennych doświadczeń, poczucie deprywacji, izolacji, znudzenia i frustracji. Taki stan sprzyja z kolei deprecjacji „swojej” wartości przestrzennej i prowadzi kobiety do poczucia wyobcowania z jedynie im dostępnej przestrzeni życiowej. Na tym polega ów „nienazwany problem” i istnienie patriarchalnie „zmistyfikowanej kobiecości" znane z książki Betty Friedan (1974). Ilustruje tę kwestię metafora domu jako pozłacanej klatki $\mathrm{z}$ kobietą $\mathrm{w}$ środku: zniewolonym ptakiem o słabym zdrowiu i bez „charakteru” (użyta blisko sto lat wcześniej przez Mary Wollstonecraft).

Choć cytowane autorki podniosły ów problem w odniesieniu do szczególnej kategorii kobiet (zamężnych, z bogatego mieszczaństwa), akcentowały negatywny wpływ braku aktywności połączonej z izolacją społeczno-przestrzenną na psychikę i osobowość każdego człowieka, bez względu na jego płeć: „Gdyby mężczyznom odmówiono możliwości rozwijania racjonalnej natury, gdyby nie pozwolono im stać się podmiotami moralnymi, gdyby nie mogli podejmować zadań, spraw, wdawać się $\mathrm{w}$ kwestie wykraczające poza ich osobistą przyjemność, to mężczyźni, podobnie jak kobiety, staliby się nadmiernie «emocjonalni»" — pisze Rosemary Putnam Tong (2002, s. 23), referując poglądy jednej z pierwszych feministek.

W patriarchacie zasadnicza zmiana sposobu doświadczania przestrzeni przez kobiety nie jest możliwa bez zmiany ich społecznego statusu na podmiotowy, a więc równy statusowi mężczyzny. Dlatego działania ruchu feministycznego na rzecz wyrównywania statusu płci (rewindykację statusu kobiet) można postrzegać także jako zorganizowane wokół żądania dla kobiet dostępu 
nie tylko do dowolnie wybranych przez nie ról społecznych, ale i do nowych przestrzeni.

Prawo do opuszczania mikroprzestrzeni rodziny i do przebywania w mezoprzestrzeniach zespołów lokalnych kobiety zdobywały stopniowo, wraz z wywalczonym dostępem do edukacji, do pracy zawodowej i do innych ról społecznych pełnionych $\mathrm{w}$ różnych grupach celowych i w zbiorowościach terytorialnych. Obecność w przestrzeni publicznej obejmującej poziom makrostrukturalny związana jest z wykonywaniem szczególnej roli — członka elity politycznej. Nawet współcześnie i nawet tam, gdzie kobiety od dawna posiadają prawa obywatelskie i legitymują się wysokim poziomem wykształcenia, doświadczanie makroprzestrzeni $\mathrm{w}$ rolach związanych $\mathrm{z}$ udziałem $\mathrm{w}$ elicie władzy nadal jest udziałem tylko nielicznych z nich.

Realną podstawą społecznej podmiotowości kobiety stało się zatem wykształcenie i niezależność ekonomiczna, jej warunkiem - posiadanie praw jednostki ludzkiej i praw obywatelskich. Jednym z empirycznych wskaźników tej podmiotowości jest nieograniczony dostęp do wszystkich typów przestrzeni oraz faktyczne posiadanie przestrzeni osobistej: symbolicznego, ale rzeczywistego „własnego pokoju” (określenie Virginii Woolf) w siedzibie rodziny patriarchalnym „niby królestwie” kobiet.

\section{ZBIOROWOŚCI PŁCI A PRZESTRZEŃ; SPOŁECZNO-PRZESTRZENNE PRZEJAWY WYRÓWNYWANIA STATUSU KOBIET I MĘŻCZYZN}

Autor teorii ekologii ludzkiej proponuje, aby przestrzeń traktowaną „ze współczynnikiem humanistycznym” zastąpić określeniem „wartość przestrzenna” i stwierdza, że „żadna z [...] wartości przestrzennych nie występuje [...] odosobniona $\mathrm{w}$ doświadczeniu ludzkim. [...]. Każda jest składnikiem jakiegoś nieprzestrzennego systemu wartości, w odniesieniu do którego posiada swoją treść i znaczenie. Może to być system religijny, estetyczny, techniczno-wytwórczy, ekonomiczny, społeczny" (Znaniecki 1938, s. 91).

W społeczeństwie patriarchalnym wartościowaniu podlegają przede wszystkim „męskość” i „kobiecość”. Wysoko cenione jest wszystko to, co składa się na tzw. kulturę męską, a więc przede wszystkim wartości bliskie mężczyznom. Wszystko to, co „kobiece”, porównywane jest ze standardami i wartościami męskimi, a uważane - za drugorzędne, trywialne, nieważne (Gilligan 1982; por. Tong 2002, s. 206; Woolf 1997). Maskulinizacja przestrzeni jest zatem jednym z najważniejszych przejawów patriarchalnego charakteru kultury, jej zaś feminizacja - rozumiana jako funkcjonowanie we wszystkich typach przestrzeni również kobiecych wzorów ról społecznych — jednym z empirycznych wskaźników procesu wyrównywania statusu społecznego płci.

Florian Znaniecki, traktując wartości przestrzenne jako elementy systemów społecznych, podjął socjologiczną analizę „umiejscowienia i ruchliwości jednostek ludzkich”. Jej celem była charakterystyka relacji między grupą („zespo- 
łem ludzkim", według określenia autora) a przestrzenią oraz między jednostką a grupą i jej przestrzenią.

Jeśli chodzi o pierwszy typ relacji, to na gruncie modelu społeczeństwa patriarchalnego warte rozważania są stosunki między każdą grupą płciową a przestrzenią.

W analizowanym modelu społeczeństwa tylko mężczyźni stanowią zorganizowany zespół mający „[...] w sferze swego zbiorowego doświadczenia i działania pewne wartości przestrzenne, które traktują jako swą wspólną «własność» [...] w tym ogólniejszym znaczeniu, że nimi wspólnie "władają" posługując się nimi dla wykonywania pewnych czynności zbiorowych lub upoważniając jednostki do posługiwania się nimi przy wykonywaniu pewnych czynności indywidualnych" (Znaniecki 1938, s. 91). Ze względu na monopol w sprawowaniu władzy (i status podmiotu) ta grupa płciowa włada przestrzenią społeczną na każdym poziomie życia społecznego. Do mężczyzn należy przestrzeń publiczna: to oni współdziałają ze sobą, realizując role w zespołach lokalnych i w ponadlokalnej przestrzeni państwa. Jako głowy rodzin $z$ kolei podejmują decyzje dotyczące przestrzeni zajmowanej przez tę grupę; co więcej - ze względu na pozycję zajmowaną $\mathrm{w}$ rodzinie oraz inne role społeczne przyznają sobie prawo do posiadania osobistej przestrzeni w siedzibie rodziny.

Kobiety w tym typie społeczeństwa nie mogą być postrzegane jako „zorganizowany zespół", ponieważ funkcjonując tylko w obrębie rodziny realizują cele i interesy tej grupy społecznej. Będąc członkiniami zbiorowości kobiet, nie tworzą grupy płciowej i w tym sensie są w społecznej izolacji od siebie; pozostają w stosunkach społecznych głównie z pozostałymi członkami rodziny, służbą i gośćmi odwiedzającymi ,ich” dom. W związku z tym nie dysponują żadną własną (tylko dla kobiet, zarządzaną przez kobiety, wykorzystywaną przez kobiety $\mathrm{w}$ działalności na rzecz innych grup) przestrzenią; w pewnych przypadkach używają jej kolektywnie do wykonywania czynności ważnych dla swej rodziny lub poszczególnych jej członków. Ograniczenie aktywności społecznej kobiet do jednego rodzaju ról społecznych i do siedziby rodziny sprawia, że wspólne fragmenty przestrzeni mają one najwyżej z kobietami współtworzącymi tę małą grupę społeczną, pozostając z nimi, jak wspomniano, w specyficznej więzi społecznej. Zespołem zawłaszczającym mikroprzestrzeń jest jednak przede wszystkim rodzina, a ona składa się z przedstawicieli obu zbiorowości płciowych.

Florian Znaniecki (1938, s. 103) wspomina, co prawda, o funkcjonowaniu „[...] u wielu ludów specjalnych grup lokalnych kobiet, zbierających się w osobnych ośrodkach". Wydaje się jednak, że wejście w przestrzeń lokalną nie legitymizowane pełnionymi tam rolami społecznymi ważnymi dla całego zespołu lokalnego jest tylko zmianą miejsca w przestrzeni geograficznej. Okazjonalne funkcjonowanie kobiecego getta pogłębia raczej społeczno-przestrzenną izolację kobiet jako kategorii społecznej, choć jednostkom może stwarzać iluzję bycia zorganizowanymi oraz dawać namiastkę zróżnicowania ich przestrzeni społecznej (Malinowska 2008). 
Analizę drugiego typu relacji, to jest między jednostką a grupą i jej przestrzenią, Florian Znaniecki poprzedza stwierdzeniem, że potencjalnie wszystkie dostępne i odpowiednie do „życia i poruszania się” przestrzenie są we władaniu jakichś zbiorowości, przede wszystkim „grup państwowych”. Tak więc „[...] żaden człowiek nie może nigdzie przebywać [...] nie wchodząc przez samą swą obecność w zakres własności przestrzennej jakiegoś zespołu" (Znaniecki 1938, s. 93). Nikt nie ma zatem pełnej swobody dostępu do dowolnej przestrzeni, a obecność każdego „W obrębie danej zespołowej wartości przestrzennej jest społecznie doświadczana jako uczestnictwo w tej wartości” (Znaniecki 1938, s. 94). W związku z tym, aby przebywać w przestrzeni będącej we władaniu danej zbiorowości, jednostka musi mieć do tego prawo.

Przypomnijmy, że z założenia o patriarchalnym charakterze najszerszych kulturowych ram funkcjonowania społeczeństwa i z tego, co powiedziano wyżej, wynika, iż poszukując przestrzeni będących zespołowymi wartościami zbiorowości płci, można znaleźć jedynie przestrzeń męską. Patriarchalne nierówności społecznego statusu płci znajdują wyraźne odzwierciedlenie w dyskryminacji kobiet, nie tylko jeśli chodzi o prawo do obecności w przestrzeniach innych niż mikroprzestrzeń, ale także o dostępny im zakres władania przestrzenią; równość społecznego statusu płci musiałaby się przejawiać $\mathrm{w}$ równym dostępie kobiet i mężczyzn do dowolnej przestrzeni (ewentualnie w podleganiu ograniczeniom dostępu nie związanym z przynależnością do danej grupy płci).

Uznanie prawa kobiet do obecności i uczestnictwa w przestrzeni publicznej, nawet jedynie w zespołach lokalnych, podwyższa ich pozycję społeczną, także w rodzinie. Rozpoczyna to proces społecznego upodmiotowienia kobiet. Zwiększa się jednak zarazem ich absencja w rolach rodzinnych, pozostawiając wolne miejsca $\mathrm{w}$ przestrzeni prywatnej. Zastąpienie $\mathrm{w}$ tych rolach kobiet aktywnych poza rodziną przez inne kobiety (siostry, matki, córki itd. ) utrwala patriarchalną zasadę płciowego podziału przestrzeni. Ze zmianą kulturową mamy do czynienia dopiero w przypadku postępującej aktywizacji mężczyzn $\mathrm{w}$ rolach rodzinnych i przestrzeni prywatnej. W społeczeństwie patriarchalnym te role i ta przestrzeń nie nobilitują jednak społecznie - jako „kobiece” są przecież niżej wartościowane. Wchodzenie kobiet w przestrzenie zmonopolizowane przez mężczyzn (zwłaszcza w przestrzeń zespołów ponadlokalnych) oraz wystąpienie swoistego przymusu aktywizacji mężczyzn w przestrzeni prywatnej (w zastępstwie dominujących tam dotychczas liczebnie kobiet) u tych drugich może zatem wywoływać niepokój przed obniżeniem się ich statusu społecznego (przedtem przynależnego dzięki legitymowaniu się „odpowiednią" płcią biologiczną).

Do pewnego czasu aktywizacja kobiet w przestrzeniach, którymi włada zespół mężczyzn, polegała na podejmowaniu ról wykonawczych, związanych z niewielkim zakresem władzy, stosunkowo nisko wynagradzanych itp. Choć proces ten miał masowy charakter, to jego znaczenie jako ewentualnie zagrażającego wysokiemu społecznemu statusowi mężczyzn było stosunkowo 
niewielkie; nadal bowiem mężczyźni niemal niepodzielnie sprawowali władzę, zwłaszcza na poziomie ponadlokalnym. Ten sam proces można jednak uznać za początek feminizacji (na razie tylko poprzez zwiększającą się liczebnie obecność kobiet) dotychczas zmaskulinizowanej przestrzeni publicznej, a masową obecność kobiet $\mathrm{w}$ zespołach lokalnych i na niższym poziomie ponadlokalnym potraktować jako przejaw szukania społeczno-przestrzennego kompromisu między kategoriami płci na drodze do egalitarnego modelu relacji między nimi.

Coraz bardziej strzeżony przez mężczyzn okazuje się tymczasem dostęp do ról zapewniających większą władzę, dochody i prestiż. Obrony wyższych pozycji i cenniejszych przestrzeni, które stają się celem kobiet, dowodzi potwierdzone empirycznie istnienie tzw. szklanego sufitu, czyli niewidzialnych i skutecznych przeszkód na drodze do zdobywania wysokich pozycji i męskich przestrzeni (Titkow 2003; Renzetti, Curran 2005).

Zastosowanie koncepcji Floriana Znanieckiego i zwrócenie uwagi na relacje między jednostką a grupą i jej przestrzenią w kontekście zagadnienia różnicy płci pozwala wyodrębnić analitycznie zachowania mężczyzny aktywizującego się $\mathrm{w}$ rolach ulokowanych $\mathrm{w}$ mikroprzestrzeni rodziny oraz zachowania kobiety wkraczającej i debiutującej w silnie bronionej przez grupę mężczyzn ekskluzywnej przestrzeni elit władzy.

Każda przedstawicielka/przedstawiciel danej zborowości płci stosuje z pewnością własne, specyficzne strategie zdobywania przestrzeni „drugiej płci”. Nie ma ryzyka w twierdzeniu, że są one naznaczone kulturowymi konstruktami płci. Co więcej - można przypuszczać, że zależą także od proporcji, w jakiej pierwiastek żeński i męski, męskość i kobiecość współwystępują w danej jednostce ludzkiej (Bem 1974). Odwołując się choćby do wyników obserwacji własnych, można pokusić się o wskazanie hipotetycznych rodzajów tych strategii, zdając sobie w pełni sprawę z konieczności empirycznej weryfikacji.

Jeśli chodzi o strategie stosowane przez mężczyznę dążącego do zachowania wysokiego statusu społecznego poprzez wzmocnienie swej pozycji w rodzinie (zwłaszcza po stracie monopolu na rolę jedynego jej żywiciela), to hipotetycznie można wyróżnić następujące strategie: (1) wspomniane wcześniej zastępowanie kobiecych wzorów zachowań męskimi, legitymizowane deprecjacją kobiecych wartości i skonstruowanych na nich wzorów zachowań („tata zrobi to inaczej i lepiej”); (2) nobilitacja czynności zwykłych, codziennych, przez kobiety traktowanych jako rutynowe (na przykład kąpanie dzieci, sprzątanie mieszkania) przez ich rytualizację, (3) podkreślanie rangi swej obecności w rodzinie (na przykład codzienny powrót z pracy traktowany jako wydarzenie niezwykłe). Odmianą tego rodzaju strategii jest uzurpowanie sobie prawa do obecności w mezoprzestrzeni będącej już we władaniu kobiet (czyli „zaszczycanie" obecnością tam, gdzie jest się intruzem, jak w damskim gabinecie kosmetycznym) albo nieoczekiwane przez grupę odgrywanie roli „mężczyzny” $\mathrm{w}$ koedukacyjnych przestrzeniach publicznych (zamiast na przykład roli referenta na seminarium naukowym). 
Stosowanie przez mężczyzn tego typu strategii może być związane z podmiotowym stosunkiem do samego siebie, $z$ wysoką oceną męskich wartości, albo przeciwnie - może być przejawem obniżania się samooceny, kompleksu powstającego na tle utraty wysokiego statusu, braku autokoncepcji.

Jeśli zaś chodzi o strategie stosowane przez kobiety dążące do zdobycia i/lub realizacji prawa do obecności $\mathrm{w}$ ekskluzywnej i elitarnej, zmaskulinizowanej przestrzeni, to hipotetycznie można wyróżnić następujące strategie: (1) przyjmowanie i realizacja męskich wzorów ról ulokowanych w tej przestrzeni (upodabnianie się do mężczyzn w wyglądzie i w sposobie zachowania); (2) legitymizowanie wejścia $\mathrm{w}$ przestrzeń publiczną wysokimi kwalifikacjami, wynikające $\mathrm{z}$ przeświadczenia, że sukces $\mathrm{w}$ konkurowaniu $\mathrm{z}$ mężczyznami o zmonopolizowane przez nich role społeczne i obiektywizację prawa do zmaskulinizowanych przestrzeni gwarantuje kobiecie jedynie posiadanie wysokiego, niebanalnego, najlepiej fromalnie potwierdzonego wykształcenia (towarzyszy tej strategii ciągła niepewność kompetencyjna, a także doświadczanie istnienia „szklanego sufitu”); (3) realizacja kulturowego ideału „kobiecości”: kobiecy ubiór, fryzura itp., nadwrażliwa jaźń odzwierciedlona, emocjonalność, demonstrowanie niepewności kompetencyjnych, kokieteria w zachowaniu zwłaszcza wobec mężczyzn, połączona $z$ odwoływaniem się do patriarchalnego wzoru relacji między „słabą kobietą” a „silnym mężczyzną” (oczekiwanie-udzielanie: zainteresowania, pomocy, wsparcia itd.); stosowaniu tej strategii mogą towarzyszyć trudności wynikające z ciągłego nieprzystosowania fizycznych cech przestrzeni publicznej do obecności i funkcjonowania tam „kobiecych” kobiet: istnienie podłóg o lustrzanym połysku, za wysokie mównice, wysokie stołki w barze, brak pokoju dla matek karmiących piersią itp. itd.; (4) strategia łącząca elementy strategii drugiej i trzeciej, czyli posiadanie wszechstronnych, profesjonalnych i wysokich kompetencji oraz wprowadzanie własnych (choćby określonych cechami z kulturowego konstruktu kobiecości, ale akceptowanych przez kobietę) wzorów zachowań w danej roli.

Stosowanie pierwszej, a częściowo także drugiej strategii utrwala zmaskulinizowanie przestrzeni i utrudnia proces formowania społecznej podmiotowości kobiety. Używanie strategii trzeciej paradoksalnie umacnia patriarchalny model stosunków płci mimo lansowania kobiecości. Jedynie strategia czwarta umożliwia podmiotowe funkcjonowanie kobiet w przestrzeni publicznej, czego przejawem jest postępujące feminizowanie przestrzeni zespołów lokalnych i ponadlokalnych.

\section{UWAGI KOŃCOWE}

Grupy kontrolują należącą do nich przestrzeń. W społeczeństwie nowoczesnym użytkowanie przestrzeni grupowej, a także zasady jej dziedziczenia, udostępniania itp. regulują przepisy prawne. W szczególności na przykład wykluczają ludzi spoza grupy z uczestnictwa społecznego $\mathrm{w}$ danej przestrzeni, 
z jej użytkowania i dziedziczenia. Te same kwestie wszędzie regulują jednak także normy obyczajowe.

Jak podkreślał Florian Znaniecki, wkraczanie w przestrzeń grupy jest konfliktogenne. Każda z płci próbuje więc chronić przestrzenie uważane za swoje przed inwazją drugiej, sadowić się i umacniać w przestrzeni, której używa, którą zdobyła, chce uznawać za swoją i którą chce władać. Przemiany modelu relacji między kategoriami płci, nakładająca się na nie konkurencja jako współcześnie popularny wzór relacji między grupami i jednostkami, a wreszcie także wpływ tendencji indywidualistycznych na działania podmiotu — wszystko to ma przestrzenne aspekty i przejawy: znajduje wyraz między innymi w stosunku grupy i jednostki do przestrzeni, także wyróżnianych z punktu widzenia płci. Dostępną powszechnej obserwacji ilustracją tej kwestii może być występowanie obecnie w przestrzeni publicznej zachowań nierozerwalnie związanych ze zróżnicowanymi płciowo fizjologicznymi potrzebami, zdolnościami i funkcjami organizmu człowieka. W zachodniej kulturze patriarchalnej właściwymi dla tego typu zachowań są nadal określone miejsca $\mathrm{w}$ przestrzeni prywatnej i publicznej; występowanie owych zachowań poza tymi miejscami przypomina wręcz, znane ze świata zwierząt, rywalizowanie o teren i jego zaznaczanie. Przykładem mogą tu być nagminnie występujące przypadki charakterystycznych zachowań mężczyzn (na przykład na parkingach przy europejskich autostradach), a ich żeńską odmianą - publiczne karmienie dziecka piersią. Zjawisko, o którym mowa, można uznać za zamach na prawo przedstawicieli/przedstawicielek drugiej płci do obecności w danej przestrzeni. Można je jednak potraktować także jako pierwotną, gdyż odwołującą się do równości płci biologicznej (tu: w prawie do przestrzeni) fazę praktycznego konstruowania równości płci kulturowej na bazie różnej, lecz równouprawnionej „natury” — androgynizacja „kultury” jako wieńcząca proces egalitaryzacji modelu relacji między kobietami i mężczyznami?

Przyjęcie teorii ekologii ludzkiej Floriana Znanieckiego, zastosowanie pojęć i twierdzeń empirycznych tej koncepcji okazuje się inspirujące i przydatne także w badaniach nad socjologiczną problematyką płci. Pozwala bowiem ukazywać społecznoprzestrzenny wymiar funkcjonowania i zmian patriarchalnego porządku społecznego, w tym interesujące problemy i aspekty procesu wyrównywania społecznego statusu płci i podmiotowości kobiet. Otwiera także i ukierunkowuje dalszą, szeroką perspektywę badawczą.

\section{BIBLIOGRAFIA}

Bem Sandra L., 1974, The Measurement of Psychological Androgyny, „Journal of Consulting and Clinical Psychology", t. 42, s. 115-162.

Bradley Harriet, 2008, Płeć, tłum. Ewa Chomicka, Sic!, Warszawa.

Friedan Betty, 1974, The Feminine Mystique, Norton, New York.

Gillian Carol, 1982, In a Different Voice: Psychological Theory of Women's Development, Harvard University Press, Harvard. 
Humm Maggie, 1993, Stownik teorii feminizmu, tłum. Bożena Umińska, Jarosław Mikos, Semper, Warszawa.

Malinowska Ewa, 2003, Mężczyźni i kobiety w spoteczeństwie jutra, „Kultura i Społeczeństwo", nr 4.

Malinowska Ewa, 2008, Pteć kulturowa a pozycja ekologiczna jednostki, w: Zbigniew Rykiel (red.), Nowa przestrzeń społeczna $w$ badaniach socjologicznych, Wydawnictwo Uniwersytetu Rzeszowskiego, Rzeszów.

Ortner Sherry B. , 1982, Czy kobieta ma się tak do mężczyzny jak „natura” do „kultury”, w: Teresa Hołówka (red.), Nikt nie rodzi się kobieta, Czytelnik, Warszawa.

Renzetti Claire M., Curran Daniel J. , 2005, Kobiety, mężczyźni $i$ spoleczeństwo, tłum. Agnieszka Gromkowska-Melosik, Wydawnictwo Naukowe PWN, Warszawa.

Titkow Anna (red.), 2003, Szklany sufit. Bariery i ograniczenia karier kobiet, Instytut Spraw Publicznych, Warszawa.

Tong Rosemarie Putnam, 2002, Myśl feministyczna. Wprowadzenie, tłum. Jarosław Mikos, Bożena Umińska, Wydawnictwo Naukowe PWN, Warszawa.

Wallis Aleksander, 1990, Socjologia wielkiego miasta, Wydawnictwo Naukowe PWN, Warszawa.

Woolf Virginia, 1997, Własny pokój, tłum. Agnieszka Graff, Sic!, Warszawa.

Znaniecki Florian, 1938, Socjologiczne podstawy ekologii ludzkiej, „Ruch Prawniczy, Ekonomiczny i Socjologiczny", z. 1.

\section{GENDER IN SOCIAL SPACE}

\section{Summary}

This work is an attempt to apply Florian Znanecki's concept of human ecology to an analysis of the functioning and transformation of a patriarchal society. It tackles the issue of the spatial aspects of how a patriarchy functions, whose identification - and especially their sociological description and explanation - become possible or more comprehensive using the said concept. These issues are (1) the impact of gender on the experience of the space and (2) gender communities vs. space - the socio-spatial manifestations of the social balancing of the status of men and women. The author's reflection is theoretical and concerns the patriarchal model of society.

\section{Key words/słowa kluczowe}

gender / płeć kulturowa; patriarchate / patriarchat; human ecology / ekologia ludzka; spatial values / wartości przestrzenne; space feminization / feminizacja przestrzeni; space masculinization / maskulinizacja przestrzeni 